\title{
Guest editorial: New research on the impact of COVID-19 on employee-owned firms and the racial wealth gap in the context of the research literature
}

We are pleased, as Co-Guest Editors, to introduce the special issue of the Journal of Participation and Employee Ownership, entitled Employee Share Ownership: The Covid-19 Pandemic and the Racial Wealth Gap. This issue was conceived as several major events and shocks were experienced by the US economy and society since January of 2020. One event was the rise of the coronavirus disease 2019 (COVID-19) pandemic and the other was the murder of the Black man George Floyd and many related tragic events. With this issue, the journal presents important contemporary research completed by nonprofit organizations in the area of employee share ownership along with new contributions in scholarly work that continue to examine important research themes related to these shocks.

News of a possible new infection started to spread in the news media in the first quarter of 2020. It was declared a Public Health Emergency of International Concern on January 20, 2020 and then a pandemic on March 11, 2020 by the World Health Organization. In February, March and April of 2020, countries began to restrict travel, close their borders, issue stay-athome orders, close schools and take other emergency measures as the virus spread along with protective measures in order to contain it and attempt to find treatments, cures and vaccines. Using a new rapid online electronic sampling technique called a pulse survey, the US Census began to study the response of US households on April 23, 2020 with the Household Pulse Survey (https://www.census.gov/programs-surveys/household-pulse-survey/data.html) while also launching the Small Business Pulse Survey (https://www.census.gov/data/ experimental-data-products/small-business-pulse-survey.html) in April of 2020 to examine the effect of changing business conditions on small businesses with fewer than 500 employees. The research notes featured in this issue were inspired by the US Census approach which sought to make initial analyses of the results available to the public and researchers quickly. As the nation with one of the largest sectors of employee-owned firms and the largest populations of employee-owners, both in majority employee-owned firms and in businesses where employees own some company stock, it made sense for researchers in this area to launch surveys in order to understand how the employee ownership sector responded to the pandemic. One goal of this Special Issue is to make available this newly emerging contemporary research quickly so that social science researchers could begin to consider the impact of the pandemic on companies with employee ownership in a timely manner.

As a result, this Special Issue features three research notes on the impact of the pandemic in the USA on employee-owned firms and employee share owners. "The response of majority employee-owned firms during the pandemic compared to other firms" by Professors Joseph Blasi, Douglas Kruse and Dan Weltmann reports on a survey completed by the respected national surveying organization, Social Science Research Survey (SSRS), on contract, for the Employee Ownership Foundation (EOF) of Washington, DC. Staff at the Institute for the Study of Employee Ownership and Profit Sharing at the Rutgers University School of Management and Labor Relations volunteered their time to develop the survey with SSRS

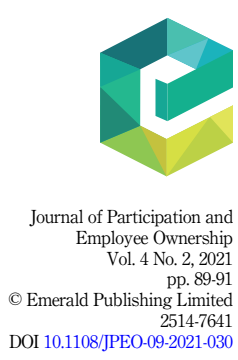


JPEO

4,2

90

and EOF and analyze these data. This survey compared the impact of the pandemic on majority employee-owned companies, mostly members of The Employee Stock Ownership Plan (ESOP) Association, to a control group of other firms that SSRS assembled to be representative of businesses with 50 or more employees nationwide. ESOPs represent most of the majority employee-owned companies in the USA, and most of these ESOPs are in The ESOP Association, which is associated with the Employee Ownership Foundation. "Member surveys on employee ownership and the COVID-19 pandemic" by Loren Rodgers reports on the impact of the pandemic on the employee-owned firms that are members of the National Center for Employee Ownership, a nonprofit that provides research and practical resources to employee-owned companies. While not a representative sample or a comparative survey, it provides deep insight and detail on how these firms responded. "When workers matter most: a study of worker cooperatives and the prioritization of workers through COVID-19" by Olga Prushinskaya, Jamie Pockrandt, Julian McKinley and Melissa Hoover reports on worker cooperatives, a less numerous but important and rapidly expanding form of employee-owned businesses. It was sponsored by the US Federation of Worker Cooperatives (USFWC), which is the major association of worker cooperatives and democratic workplaces, and the Democracy at Work Institute (DAWI), its associated research organization. This study uses DAWI's regular census of cooperatives to examine the impact of the COVID-19 pandemic on individual firms. While also not a representative sample or a comparative survey, it provides deep insight and detail on how the worker cooperative sector of employee-owned firms responded. The editors of this Special Issue believe it is a scholarly and research priority to provide these reports and introduce access to these data as social scientists are trying to figure out these impacts.

The murder of the Black man George Floyd and the many related tragic events that documented the plight of Black people in the USA in 2020 and 2021 engendered a strong response and a powerful impact on the US population regarding systemic racism and the social, economic and political gaps that Black people experience. The Aspen Institute's Economic Opportunity Program, the Rutgers Institute for the Study of Employee Ownership and Profit Sharing, and the DAWI initiated an initial study of how racism and the social, economic and political gaps that Black people experience may be affected by employee ownership. The article, "Race and gender wealth equity and the role of employee share ownership" is by Jenny Weissbourd, Maureen Conway, Joyce Klein, Yoorie Chang, Douglas Kruse, Melissa Hoover, Todd Leverette, Julian McKinley and Zen Trenholm of the Aspen Institute and the DAWI. It begins to explore these difficult issues. It builds on one of the first comprehensive research studies, "Building the Assets of Low and Moderate Income Workers and Their Families: The Role of Employee Ownership," supported by the W.K. Kellogg Foundation and conducted by a national team of researchers at the Rutgers Institute for the Study of Employee Ownership and Profit Sharing in 2019 (https://smlr.rutgers.edu/sites/ default/files/Documents/Centers/Institute_Employee_Ownership/rutgerskelloggreport_ april2019.pdf).

When we conceived this special issue with its focus on contemporary events and the important contributions that timely reports by a range of organizations could make, we wanted to place this work in a broader context of employee ownership research and practice. The review article, "Employee ownership - pros and cons - a review" by Neils Mygind and Thomas Poulsen of the Copenhagen Business School provides just such a comprehensive and deep theoretical and empirical review of the employee ownership idea. We want to particularly call the reader's attention to the fact that many of the findings of this encyclopedic and sophisticated review - for example, on the employment stability of employee-owned enterprises and the unique culture they attempt to develop - are reflected by the new empirical results and illustrations of the COVID impact surveys. Moreover, as the article on employee ownership and the racial wealth gap illustrates, the employee ownership 
world still faces significant cultural challenges. The article "Does participation in the workplace spill over into political participation? A latent class analysis approach to patterns of political behavior" by Jung ook Kim provides new empirical insight on the underexplored issue of how employee ownership is related to civic behavior. It is particularly relevant in this Special Issue where civic behavior, national crisis, cultural conflict and employee ownership, all find a part. Finally, with the case study, "Case study: Central States Manufacturing, Inc" by Dr. Adria L. Scharf, Beyster Fellow and Project Director of the Curriculum Library of Employee Ownership ( www.cleo.rutgers.edu) we introduce what we hope will be a frequent contribution of the Journal, namely, timely serious interdisciplinary case studies of different forms and formats of employee ownership that will allow the reader to assign ethnographic detail and specific historical context to these phenomena.

Joseph Blasi and Douglas Kruse

School of Management and Labor Relations, Rutgers University, Piscataway, New Jersey, USA, and

Dan Weltmann Ancell School of Business, Western Connecticut State University, Danbury, Connecticut, USA 